\title{
Protease supplementation in maize-based diet influenced net energy and nutrient digestibility in broilers
}

\author{
K.W. McCafferty ${ }^{1}$, A.F. Moss ${ }^{1}$, N.K. Morgan ${ }^{1 *}$, A.J. Cowieson ${ }^{2}$ and M. Choct ${ }^{1}$ \\ ${ }^{1}$ School of Environmental and Rural Sciences, University of New England, Armidale, NSW, 2351, Australia; ${ }^{2}$ DSM Nutritional \\ Products, Kaiseraugst 4303, Switzerland; nmorga20@une.edu.au
}

Received: 3 June 2021 / Accepted: 28 June 2021

(c) 2021 K.W. McCafferty

RESEARCH ARTICLE POULTRY

\begin{abstract}
This experiment evaluated the effects of supplemental protease in maize-based diets formulated with reduced density of digestible amino acids (dAA) on net energy (NE) utilisation and nutrient digestibility in broilers. A total of 312, one-day-old, male broilers (Ross 308 ) were randomly distributed into 24 floor pens and fed one of three treatments, with eight pen replicates per treatment throughout the starter ( 1 to $14 \mathrm{~d}$ of age) and grower (15 to $28 \mathrm{~d}$ of age) phases. Dietary treatments consisted of a positive control (PC) reference diet, a negative control diet (NC; dAA density $60 \mathrm{~g} / \mathrm{kg}$ less than PC diet), and a NC diet with supplemental protease $(200 \mathrm{mg} / \mathrm{kg})$. All diets contained supplemental phytase $(200 \mathrm{mg} / \mathrm{kg})$ and xylanase $(200 \mathrm{mg} / \mathrm{kg})$. The reduction in dAA density between the PC and $\mathrm{NC}$ did not affect $(P>0.05) \mathrm{NE}$, but protease supplementation in the $\mathrm{NC}$ diet increased $(P<0.05) \mathrm{NE}$ by $0.27 \mathrm{MJ} / \mathrm{kg}$, compared with those receiving the NC diet without protease. The reduction in dAA for broilers fed the NC and PC diets did not $(P>0.05)$ affect nitrogen, starch, or DE in the jejunum or ileum. Likewise, no differences $(P>0.05)$ in jejunal (nitrogen, starch, and DE) and ileal (starch and DE) digestibility values were observed between those offered the NC diets without or with protease, but a small difference $(P<0.05)$ in ileal nitrogen digestibility was observed.
\end{abstract}

Keywords: broilers, digestibility, net energy, protease

\section{Introduction}

Modulating broiler digestive dynamics can affect nutrient utilisation, growth performance and economics of production. Technical feed ingredients, such as monocomponent phytase and xylanase enzymes, have been widely researched and applied as tools for accomplishing these objectives. Likewise, the development and application of mono-component protease enzymes have been observed to modulate broiler digestive dynamics, with protease supplementation reported to increase average ileal amino acid (AA) digestibility by $3.74 \%$ (Cowieson and Roos, 2014). Cowieson et al. (2019) demonstrated that protease supplementation, in conjunction with a phytase and xylanase, influenced AA digestibility, apparent metabolisable energy (AME) and net energy (NE) utilisation in broilers. Moreover, these authors observed that the increase in NE was more pronounced than seen in AME ( 4.5 vs $2.3 \%$, respectively), indicating that protease may affect energy partitioning and maintenance requirements in broilers (Cowieson et al., 2019).

Moreover, market and legislative demands to reduce $\mathrm{N}$ excretion and antibiotic usage has led to increased emphasis on formulating lower crude protein diets (Lemme et al., 2019; Vieira and Lima, 2005). These alterations can affect nutrient balance and digestible AA (dAA), which can affect nutrient utilisation and performance, if not accounted for in the least-cost formulation. Therefore, the objective of this experiment was to explore the effects of protease supplementation, in combination with phytase and xylanase, in a plant protein, maize-based diet formulated with reduced concentrations of dAA on nutrient digestibility and net energy utilisation in broilers. 


\section{Materials and methods}

The use of live birds for this experiment was approved by the University of New England Animal Ethics Committee (19-083), which complied with the Australian Code of Practice for the Care and Use of Animal for Scientific Purposes (National Health and Medical Research Council, 2013).

\section{Husbandry}

A total of 312 unvaccinated male broiler chicks (Ross 308) were obtained from a commercial hatchery and randomly distributed into 24 floor pens $\left(0.07 \mathrm{~m}^{2}\right.$ per bird) across two environmentally controlled rooms. Each pen was equipped with fresh wood shavings $(6 \mathrm{~cm}$ depth) as bedding material, two nipple cup drinkers and a hanging pan feeder. Access to feed and water was provided ad libitum throughout the experiment. Room temperature was initially set at $34{ }^{\circ} \mathrm{C}$ and was gradually reduced as birds advanced in age to $24^{\circ} \mathrm{C}$ at $35 \mathrm{~d}$ of age. Photoperiod was set at 23L: 1D from one to six d of age, and then 20L: 4D from seven to $35 \mathrm{~d}$ of age.

\section{Dietary treatments}

Three dietary treatments (maize-based diets) were offered during the starter (one to 14 d of age) and grower (15 to 28 d of age) phases (Table 1). Dietary treatments consisted of a positive control (PC) reference diet, a negative control $\operatorname{diet}(\mathrm{NC})$ (dAA density $60 \mathrm{~g} / \mathrm{kg}$ less than the PC diet), and the NC diet with supplemental protease $(15,000 \mathrm{U} / \mathrm{kg})$. Varying dAA densities between the PC and NC diets were achieved by reducing digestible Lys concentrations, because all dietary treatments were formulated on a dAA to digestible Lys ratio. Additionally, all diets contained a monocomponent phytase (RONOZYME HIPhos GT; 10,000 FYT/g) and xylanase (RONOZYME WX CT; 1000 FXU/g), expressed from strains of Aspergillus oryzae, to achieve infeed activity of 2,000 FYT/kg and $200 \mathrm{FXU} / \mathrm{kg}$, respectively (DSM Nutritional Products, Kaiseraugst, Switzerland). Phytase matrix values were applied at $0.15 \% \mathrm{Ca}$ and $0.15 \% \mathrm{P}$, but no matrix value was applied for xylanase. A mono-component, serine protease (RONOZYME ProAct CT, DSM Nutritional Products) expressed by Bacillus licheniformis, providing 75,000 PROT U/g, was included in the NC supplemented treatment to achieve a feed activity of 15,000 PROT U/kg. No matrix value was applied for the supplemental protease. Basal diets were formulated with $0.03 \%$ washed builder's sand, which was partially substituted with protease in the NC supplemented treatment $(0.02 \%$ protease $+0.01 \%$ sand). Titanium dioxide was included as an indigestible marker in all diets.

Ingredient (maize and soybean meal) subsamples were analysed by near-infrared spectroscopy for proximate analysis, dAA concentrations and AME using AMINONIR ${ }^{\circledR} \mathrm{PROX}$,
AMINONIR ${ }^{\oplus}$ NIR, and AMINONIR ${ }^{\circledR}$ NRG (Evonik Nutrition \& Care, Hanua, Germany), respectively.

The PC reference diet was formulated to have a specification close to the breeder recommendations (Ross, 2014) for all nutrients except AME, which was approximately 0.42 and $0.32 \mathrm{MJ} / \mathrm{kg}$ below the average starter and grower phase recommendations, respectively, to reduce the concentration of supplemental lipids. All diets were cold-pelleted $\left(65^{\circ} \mathrm{C}\right)$ through a $3 \mathrm{~mm}$ die prior to feeding. Feed form consisted of crumbles during the starter phase and pellets thereafter. Feed enzyme activity concentrations of phytase, xylanase, and protease were determined in all experimental treatments by a commercial laboratory (DSM Nutritional Products Australia Pty Ltd, Wagga Wagga, Australia).

\section{Indirect calorimetry}

At $17 \mathrm{~d}$ of age, 30 birds (two birds/pen from five replicate pens) were transferred into 15 closed-circuit calorimeter chambers. A $3 \mathrm{~d}$ acclimatation period was provided and birds remained on their respective dietary treatments. From 21 to $24 \mathrm{~d}$ of age, chambers were closed and used to measure heat production (HP), AME and NE by gaseous exchange and total collection of excreta, respectively. Oxygen consumption was determined by the difference in gas cylinder weights at the beginning and end of each $24 \mathrm{~h}$ run cycle, which was converted to volume by density (1.331 g/l). Carbon dioxide was trapped in $32 \% \mathrm{KOH}$ solution and determined gravimetrically using barium precipitation, as described by Annison and White (1961). The concentrations of $\mathrm{O}_{2}$ consumption and $\mathrm{CO}_{2}$ expiration were used to calculate HP, using the Brouwer (1965) equation. No correction for uric acid nitrogen excretion was employed. Respiratory quotient (RQ) of the 3-day run was calculated as the volume of $\mathrm{CO}_{2}$ produced to the volume of $\mathrm{O}_{2}$ consumed.

\section{Apparent metabolisable energy, heat production and net energy determination}

At approximately the same time on each day of the $3 \mathrm{~d} N E$ assay, chambers were opened, birds and feed were weighed and total excreta samples were collected. Subsamples were collected and homogenised from the total excreta collected over the entire assay to determine gross energy (GE) and nitrogen content, allowing for calculation of energy intake and excretion. The AME of the diets was calculated on a DM basis, according to Equation 1:

$\operatorname{AME}(\mathrm{kcal} / \mathrm{kg})=\left(\mathrm{GE}_{\text {intake }}-\mathrm{GE}_{\text {excreta }}\right) /$ feed intake

Net energy intake and of the diets were calculated as described by Noblet et al. (1994). In birds, the fasting heat production value plus the retained energy (RE) equals NE intake. Thus, RE was calculated by subtracting HP 
Table 1. Ingredient and nutrient composition of positive (PC) and negative (NC) control diets fed to Ross 308 male broilers.

\begin{tabular}{|c|c|c|c|c|}
\hline \multirow[t]{2}{*}{ Ingredient, g/kg 'as-fed' } & \multicolumn{2}{|c|}{1 to $14 \mathrm{~d}$ of age } & \multicolumn{2}{|c|}{15 to $28 \mathrm{~d}$ of age } \\
\hline & PC & NC & PC & NC \\
\hline $\begin{array}{l}\text { Maize } \\
\text { Soybean meal } \\
\text { Canola oil } \\
\text { Calcium carbonate } \\
\text { Dicalcium phosphate } \\
\text { Sodium chloride } \\
\text { Sodium bicarbonate } \\
\text { Vitamin premix } \\
\text { Mineral premix } \\
\text { Choline chloride } \\
\text { L-Lys } \cdot \mathrm{HCl} \\
\text { DL-Methionine } \\
\text { L-Thr } \\
\text { Phytase } \\
\text { Xylanase } \\
\text { Sand }^{3} \\
\text { Titanium dioxide }\end{array}$ & $\begin{array}{r}608.5 \\
311.2 \\
37.3 \\
10.7 \\
10.0 \\
1.9 \\
1.9 \\
0.9 \\
1.0 \\
3.8 \\
3.0 \\
3.1 \\
1.0 \\
0.2 \\
0.2 \\
0.3 \\
5.0\end{array}$ & $\begin{array}{r}639.9 \\
284.5 \\
33.0 \\
10.9 \\
10.0 \\
1.9 \\
2.0 \\
0.9 \\
1.0 \\
3.8 \\
2.9 \\
2.8 \\
0.9 \\
0.2 \\
0.2 \\
0.3 \\
5.0\end{array}$ & $\begin{array}{r}642.9 \\
267.7 \\
46.9 \\
10.9 \\
10.2 \\
1.9 \\
2.0 \\
0.9 \\
1.0 \\
3.8 \\
2.8 \\
2.6 \\
0.8 \\
0.2 \\
0.2 \\
0.3 \\
5.0\end{array}$ & $\begin{array}{r}669.7 \\
244.8 \\
43.2 \\
11.0 \\
10.3 \\
2.0 \\
2.0 \\
0.9 \\
1.0 \\
3.8 \\
2.7 \\
2.3 \\
0.7 \\
0.2 \\
0.2 \\
0.3 \\
5.0\end{array}$ \\
\hline \multicolumn{5}{|c|}{ Calculated nutrient content ( $\mathrm{g} / \mathrm{kg}$, unless otherwise indicated) } \\
\hline $\begin{array}{l}\text { AME, MJ/kg } \\
\text { Starch } \\
\text { Crude Protein } \\
\text { SID }{ }^{5} \text { Lys } \\
\text { SID Met } \\
\text { SID TSAA } \\
\text { SID Thr } \\
\text { SID Val } \\
\text { SID Arg } \\
\text { SID Trp } \\
\text { Ca } \\
\text { Non-phytate P } \\
\text { Na }\end{array}$ & $\begin{array}{c}12.34 \\
396.8 \\
209.5 \\
11.8 \\
5.9 \\
8.6 \\
7.6 \\
8.7 \\
12.2 \\
2.1 \\
9.0 \\
4.5 \\
1.8\end{array}$ & $\begin{array}{c}12.34 \\
417.0 \\
199.8 \\
11.1 \\
5.4 \\
8.1 \\
7.1 \\
8.3 \\
11.4 \\
2.0 \\
9.0 \\
4.5 \\
1.8\end{array}$ & $\begin{array}{c}12.76 \\
418.8 \\
191.7 \\
10.6 \\
4.5 \\
7.7 \\
6.8 \\
8.0 \\
10.9 \\
1.9 \\
9.0 \\
4.5 \\
1.9\end{array}$ & $\begin{array}{r}12.76 \\
436.1 \\
183.1 \\
10.0 \\
4.2 \\
7.3 \\
6.4 \\
7.7 \\
10.3 \\
1.8 \\
9.0 \\
4.5 \\
2.0\end{array}$ \\
\hline
\end{tabular}

${ }^{1}$ Vitamin premix supplied per kilogram of diet: retinol, $12,000 \mathrm{IU}$; cholecalciferol, 5,000 IU; tocopheryl acetate, $75 \mathrm{mg}$, menadione, $3 \mathrm{mg}$; thiamine, $3 \mathrm{mg}$; riboflavin, $8 \mathrm{mg}$; niacin, $55 \mathrm{mg}$; pantothenate, $13 \mathrm{mg}$; pyridoxine, $5 \mathrm{mg}$; folate, $2 \mathrm{mg}$; cyanocobalamin, $16 \mu \mathrm{gg}$; biotin, $200 \mu \mathrm{g}$; cereal-based carrier, $149 \mathrm{mg}$; mineral oil, $2.5 \mathrm{mg}$. ${ }^{2}$ Trace mineral premix supplied per kilogram of diet: Cu (sulphate), $16 \mathrm{mg}$; Fe (sulphate), $40 \mathrm{mg}$; I (iodide), $1.25 \mathrm{mg}$; Se (selenate), $0.3 \mathrm{mg} ; \mathrm{Mn}$ (sulphate and oxide), $120 \mathrm{mg}$; Zn (sulphate and oxide), $100 \mathrm{mg}$; cereal-based carrier, $128 \mathrm{mg}$; mineral oil, $3.75 \mathrm{mg}$.

${ }^{3}$ RONOZYME $^{\circ} \mathrm{HiPhos}$ and RONOZYME ${ }^{\circ} \mathrm{WX}$ were used as sources of phytase and xylanase, respectively. A phytase matrix value of $1.5 \mathrm{~g} / \mathrm{kg}$ for both Ca and digestible $\mathrm{P}$ was used. No energy matrix was applied to xylanase.

${ }^{4}$ Sand was the variable portion in diet formulation. Protease (RONOZYME ${ }^{\circ}$ ProAct was either included at 0 or $200 \mathrm{mg} / \mathrm{kg}$ to the NC basal diets at the expense of sand to achieve the 2 dietary treatments (NC diets without or with supplemental protease).

${ }^{5} \mathrm{SID}=$ standardised ileal digestible values. Diets were formulated on digestible AA basis using SID values predicted by AMINO NIR (Evonik Nutrition \& Care, Hanua, Germany).

from metabolisable energy intake (MEI). Fasting heat production (FHP) of $450 \mathrm{~kJ} / \mathrm{BW}^{0.70}$ per day was used, which corresponded to the asymptotic HP (at zero activity) estimated by Noblet et al. (2015). Heat increment (HI) of feeding was calculated by subtracting fasting heat production from total heat production. The NE value of the diet was calculated as follows:

$\mathrm{NE}=(\mathrm{RE}+\mathrm{FHP}) /$ feed intake

Diet and excreta samples were lyophilised using a Christ Alpha 1-2LDplus Freeze Dryer (Martin Christ Gefriertrocknungsanlagen, Osterode, Germany). The dry matter of wet samples was determined using a forced air oven at $105^{\circ} \mathrm{C}$ for $12 \mathrm{~h}$ to a constant weight. GE was determined using a 6400 automatic isoperibol oxygen bomb calorimeter (Parr Instruments, Moline, IA, USA). Nitrogen content was determined by the Dumas combustion method (method 990.03; AOAC, 2005) with a LECO FP-200 N analyser (Leco Corp., St. Joseph, MI, USA), using a $\mathrm{N}$ correction factor of 6.25 for crude protein (CP) determination.

\section{Apparent jejunal and ileal digestibility}

At $28 \mathrm{~d}$ of age, three birds per cage were randomly selected, weighed, and euthanised by cervical dislocation for collection of jejunal and ileal digesta contents. Digesta contents from the entire jejunum (end of the duodenal loop to the Meckel's diverticulum) and ileum (Meckel's diverticulum to the ileo-caecal junction) were gently squeezed into polypropylene cups. Samples were pooled 
per cage and frozen at $-20{ }^{\circ} \mathrm{C}$ prior to analysis. Diets and digesta samples were lyophilised to a constant weight using a Christ Alpha 1-2LD plus Freeze Dryer (Martin Christ Gefriertrocknungsanlagen), and then ground through a $0.5 \mathrm{~mm}$ screen and analysed for nitrogen, starch, and GE. Nitrogen and CP content were determined by the aforementioned method. Starch concentration was determined enzymatically using the Megazyme Total Starch Assay Kit (Megazyme Int., Wicklow, Ireland). Gross energy was determined using a 6400 automatic isoperibol oxygen bomb calorimeter (Parr Instruments). Additionally, diets and digesta were analysed for titanium dioxide $\left(\mathrm{TiO}_{2}\right)$ concentration in quadruplicate and duplicate replicates, respectively, by the method described by Short et al. (1996). Apparent jejunal and ileal digestibility coefficients (DC) for nitrogen, starch, and energy were calculated on a DM basis using Equation 3:

$$
\begin{aligned}
& \text { Apparent DC }(\%)= \\
& \frac{\left(\frac{\text { Nutrient }}{\mathrm{TiO}_{2}}\right) \text { diet }-\left(\frac{\text { Nutrient }}{\mathrm{TiO}_{2}}\right) \text { digesta }}{\left(\frac{\text { Nutrient }}{\mathrm{TiO}_{2}}\right) \text { diet }} \times 100
\end{aligned}
$$

where nutrient corresponded to nitrogen, starch, or GE. Moreover, apparent digestible energy (DE) was calculated using Equation 4:

Apparent DE $(\mathrm{kcal} / \mathrm{kg})=\mathrm{GE}_{\text {diet }} \times \frac{\text { Apparent DC of energy }}{100}$

\section{Statistics}

The experiment was arranged as a randomised complete block design with pen location as the blocking factor, with a one-way treatment structure and 6 replicate pens per treatment. Data were analysed using a one-way ANOVA in PROC MIXED (SAS, 2015). Preplanned orthogonal contrasts with $2 \mathrm{df}$ were used to determine treatment effects between: (1) PC vs NC; and (2) NC vs NC with supplemental protease treatments. Statistical significance was established at $P \leq 0.05$.

\section{Results}

\section{Dietary enzyme activity}

Dietary phytase, xylanase, and protease activity concentrations of the starter and grower diets are shown in Table 2. Overall, the analysed dietary enzyme activity concentrations were within an acceptable range compared with the formulated values.

\section{Energy partitioning}

The effects of dietary treatments on energy partitioning are presented in Table 3 . No differences $(P>0.05)$ in AME, NE, HP, and HI were observed between broilers offered the $\mathrm{PC}$ and $\mathrm{NC}$ diets. However, broilers receiving the NC diet with supplemental protease had a 0.31 and $0.27 \mathrm{MJ} / \mathrm{kg}$ higher $(P<0.05)$ AME $(P=0.01)$ and NE $(P=0.03)$, respectively, compared with those offered the $\mathrm{NC}$ diet without supplemental protease. However, no differences $(P>0.05)$ in HP or HI were observed between the NC diets with or without supplemental protease.

\section{Digestibility}

The effects of dietary treatments on apparent digestibility of nitrogen, starch and energy in the jejunum and ileum are shown in Table 4 . The reduction in dAA between broilers fed the NC and PC diets did not $(P>0.05)$ affect nitrogen, starch, or DE in the jejunum or ileum. Likewise, no differences $(P>0.05)$ in jejunal (nitrogen, starch, and DE) or ileal (starch and DE) digestibility were observed between those offered the NC diets without or with protease. However, broilers receiving the NC diet with protease had slightly lower ileal nitrogen digestibility $(P=0.05)$ compared with those receiving the $\mathrm{NC}$ diet without protease.

\section{Discussion}

The utilisation of dietary energy by chickens depends on several factors, including the overall quality of the ingredients, balance of the diet, and health status of the bird (Kleyn and Chrystal, 2020). Furthermore, true availability of energy requires consideration of additional ingredient characteristics when formulating a diet; such as the partitioning and the effect of certain nutrients on heat production (Emmans, 1994; Lopez and Leeson, 2008). Wu et al. (2019) and Barzegar et al. (2020) presented a series of equations to predict the net energy values of feed ingredients for both broilers and layers, and some of the key influencers were shown to be ether extract, non-starch polysaccharides and CP.

The current study examined whether a reduction in dietary protein by lowering dAA concentrations would have any effect on net energy, and whether protease supplementation would enhance net energy. The results demonstrated that reducing protein from 19.2 to $18.3 \%$ during the net energy trial period did not affect AME or NE values. However, protease supplementation significantly increased both AME and NE of the NC diet. There was a numerical difference in heat increment between the $\mathrm{NC}$ and $\mathrm{NC}+$ protease treatments ( 0.363 vs 0.324 , respectively; $P=0.14$ ), which suggested that exogenous protease affected energy expenditure associated with digestion or maintenance processes in poultry. Mahagna et al. (1995) observed that broilers fed a sorghum-soybean meal-based diet containing supplemental protease and amylase $(1000 \mu \mathrm{g} / \mathrm{kg})$ had lower concentrations of chymotrypsin in the pancreas and intestinal contents compared with those offered the control diet at both seven and $14 \mathrm{~d}$ of age. Similarly, at $14 \mathrm{~d}$ 
Table 2. Analysed phytase, xylanase, and protease activity concentrations of the starter and grower diets. ${ }^{1}$

\begin{tabular}{|c|c|c|c|c|c|c|}
\hline \multirow[b]{2}{*}{ Dietary treatment } & \multicolumn{3}{|l|}{1 to $14 \mathrm{~d}$ of age } & \multicolumn{3}{|l|}{15 to $28 \mathrm{~d}$ of age } \\
\hline & Protease $^{2}$ (PROT/kg) & Xylanase $^{3}$ (FXU/kg) & Phytase $^{4}$ (FYT/kg) & Protease (PROT/kg) & Xylanase (FXU/kg) & Phytase (FYT/kg) \\
\hline $\begin{array}{l}\mathrm{NC} \\
\mathrm{NC}+\text { Protease } \\
\mathrm{PC}\end{array}$ & $\begin{array}{l}\text { na }^{5} \\
14,020 \\
\text { na }\end{array}$ & $\begin{array}{l}133 \\
218 \\
244\end{array}$ & $\begin{array}{l}2,535 \\
2,185 \\
2,719\end{array}$ & $\begin{array}{l}\text { na } \\
13,930 \\
\text { na }\end{array}$ & $\begin{array}{l}210 \\
159 \\
164\end{array}$ & $\begin{array}{l}2,365 \\
2,172 \\
1,970\end{array}$ \\
\hline
\end{tabular}

${ }^{1}$ Values represent average of duplicate replicate samples on a 'as is' basis. Enzyme activity concentrations were determined by an outside laboratory (DSM BioPract $\mathrm{GmbH}$, Berlin, Germany). NC = negative control; $\mathrm{PC}=$ positive control.

2 Protease $=$ RONOZYME ${ }^{\circ}$ ProAct (DSM Nutritional Products, Kaiseraugst, Switzerland) which provides 75,000 PROT/g was included in the supplemental treatments at $200 \mathrm{mg} / \mathrm{kg}$ to achieve a protease activity of $15,000 \mathrm{PROT} / \mathrm{kg}$.

${ }^{3}$ Xylanase $=$ RONOZYME ${ }^{\circ}$ WX (DSM Nutritional Products) which provides $1000 \mathrm{FXU} / \mathrm{g}$ was included in all supplemented treatments at $200 \mathrm{mg} / \mathrm{kg}$ to achieve a xylanase activity of $200 \mathrm{FXU} / \mathrm{kg}$.

${ }^{4}$ Phytase $=$ RONOZYME ${ }^{\oplus}$ HiPhos (DSM Nutritional Products) which provides $10,000 \mathrm{FYT} / \mathrm{g}$ was included in all treatments at $200 \mathrm{mg} / \mathrm{kg}$ to achieve a phytase activity of 2,000 FYT/kg.

${ }^{5} \mathrm{na}=$ not analysed.

Table 3. Apparent metabolisable energy (AME), net energy (NE), heat production (HP), and heat increment (HI) of Ross 308 male broilers fed maize-based diets without and with supplemental protease from 19 to $21 \mathrm{~d}$ of age. ${ }^{1,2}$

\begin{tabular}{|c|c|c|c|c|}
\hline Dietary treatment ${ }^{3}$ & AME (MJ/kg) & NE (MJ/kg) & $\mathrm{HP}\left(\mathrm{MJ} / \mathrm{kg} \mathrm{BW} \mathrm{BW}^{0.70}\right)$ & $\mathrm{HI}\left(\mathrm{MJ} / \mathrm{kg} \mathrm{BW} \mathrm{B}^{0.70}\right)$ \\
\hline $\begin{array}{l}\text { NC } \\
\text { NC + Protease } \\
\text { PC } \\
\text { SEM }\end{array}$ & $\begin{array}{r}15.63 \\
15.94 \\
15.77 \\
0.07\end{array}$ & $\begin{array}{r}12.17 \\
12.44 \\
12.32 \\
0.07\end{array}$ & $\begin{array}{l}0.816 \\
0.809 \\
0.807 \\
0.012\end{array}$ & $\begin{array}{l}0.363 \\
0.324 \\
0.342 \\
0.017\end{array}$ \\
\hline Pre-planned orthogonal contrasts & Probabilities & & & \\
\hline $\begin{array}{l}\mathrm{NC} \text { vs NC + Protease } \\
\mathrm{NC} \text { vs PC }\end{array}$ & $\begin{array}{l}0.01 \\
0.21\end{array}$ & $\begin{array}{l}0.03 \\
0.19\end{array}$ & $\begin{array}{l}0.65 \\
0.60\end{array}$ & $\begin{array}{l}0.14 \\
0.43\end{array}$ \\
\hline
\end{tabular}

${ }^{1}$ Feed and digesta were analysed in quadruplicate and duplicate, respectively. Values are expressed on a DM basis.

2 Values are least-square means of 5 replicate cages with 2 birds per chamber.

3 Dietary treatment consisted of maize-based diets with 3 possible treatments: (1) Negative control (NC; amino acid density $60 \mathrm{~g} / \mathrm{kg}$ below the PC); (2) NC + 200 mg/kg ProAct; (3) Positive control (PC).

Table 4. Apparent jejunal and ileal nitrogen and starch digestibility and digestible energy of Ross 308 male broilers fed maize-based diets without or with supplemental protease at $28 \mathrm{~d}$ of age.,

\begin{tabular}{|c|c|c|c|c|}
\hline Intestinal section & Treatment $^{3}$ & Nitrogen $(\%)$ & Starch (\%) & $\mathrm{DE}^{4}(\mathrm{MJ} / \mathrm{kg})$ \\
\hline $\begin{array}{l}\text { Jejunum } \\
\text { Ileum }\end{array}$ & $\begin{array}{l}\text { NC } \\
\text { NC + Protease } \\
\text { PC } \\
\text { SEM } \\
\text { NC } \\
\text { NC + Protease } \\
\text { PC } \\
\text { SEM }\end{array}$ & $\begin{array}{c}60.01 \\
64.12 \\
65.00 \\
2.2 \\
84.36 \\
82.69 \\
84.01 \\
0.53\end{array}$ & $\begin{array}{r}87.42 \\
86.19 \\
87.19 \\
0.85 \\
96.81 \\
96.46 \\
96.67 \\
0.54\end{array}$ & $\begin{array}{r}11.42 \\
11.76 \\
11.94 \\
0.19 \\
15.08 \\
15.04 \\
15.29 \\
0.10\end{array}$ \\
\hline Pre-planned orthogonal contrasts & Probabilities & & & \\
\hline $\begin{array}{l}\text { Jejunum } \\
\text { Ileum }\end{array}$ & $\begin{array}{l}\text { NC vs NC + Protease } \\
\text { NC vs PC } \\
\text { NC vs NC + Protease } \\
\text { NC vs PC }\end{array}$ & $\begin{array}{l}0.19 \\
0.13 \\
0.05 \\
0.67\end{array}$ & $\begin{array}{l}0.31 \\
0.85 \\
0.50 \\
0.80\end{array}$ & $\begin{array}{l}0.24 \\
0.08 \\
0.81 \\
0.14\end{array}$ \\
\hline
\end{tabular}

${ }^{1}$ Feed and digesta were analysed in duplicate.

2 Values are least-square means represent 8 replicate pens from 3 birds per pen.

${ }^{3}$ Dietary treatment consisted of maize-based diets with 3 possible treatments: (1) Negative control (NC; amino acid density $60 \mathrm{~g} / \mathrm{kg}$ below the PC); (2) NC + $200 \mathrm{mg} / \mathrm{kg}$ ProAct; (3) Positive control (PC).

${ }^{4} \mathrm{DE}=$ digestible energy. 
of age, broilers fed the diets supplemented with protease and amylase showed reduced concentrations of amylase in the intestinal contents compared with those fed the control diet (Mahagna et al., 1995). Therefore, exogenous enzyme supplementation may affect endogenous secretions and could partially explain the observed improvement in net energy seen with supplemental protease. However, additional factors, such as feed intake, may affect FHP and maintenance energy requirements through alterations in organ size and muscle protein turnover rate (Labussiere et al., 2011; Liu et al., 2017). Therefore, additional research evaluating these factors is warranted.

In this study, both jejunal and ileal digestibility were measured, because protease supplementation has been observed to increase nutrient digestibility in more proximal regions of the small intestine (Liu et al., 2013). The argument that additional protein was degraded by protease was not clearly demonstrated in the nitrogen digestibility results, although, in the jejunum, positive numerical differences in nitrogen digestibility were observed, which appeared to follow this hypothesis. For example, jejunal nitrogen digestibility values of broilers offered the $\mathrm{NC}$ and $\mathrm{NC}+$ protease were 60.01 and $64.12 \%$, respectively. However, these differences were not significant $(P=0.19$; $\mathrm{SEM}=2.2$ ), due to the level of variation in digestibility observed within the jejunal contents. Moreover, an opposite and significant effect was observed in the ileum, with those offered $\mathrm{NC}+$ protease having lower ileal nitrogen digestibility $(P=0.05$; $\mathrm{SEM}=0.53$ ) compared with those fed the NC diet without protease ( 82.69 vs $84.36 \%$, respectively). These inverse responses could be due to differences in insoluble nonstarch polysaccharide concentrations from the action of the other exogenous enzymes, which, in turn, increased rate of passage and endogenous AA losses. For example, exogenous enzyme supplementation has been observed to increase broiler rate of passage (Almirall and Esteve-Garcia, 1994; Lazaro et al., 2003). Moreover, increased concentrations of insoluble fibre have been observed to increase ileal endogenous AA losses (Kluth and Rodehutscord, 2009). However, additional experiments evaluating the interactive effects of various mono-component enzymes and their end products on nutrient digestibility and endogenous AA losses is warranted to test the validity of this response and hypothesis.

There were no differences in starch digestibility in the jejunum or ileum, but the current study confirmed that this parameter increased progressively as the digesta moved from the proximal to the distal part of the small intestine (Riesenfeld et al., 1980). As starch is the main source of energy for poultry diets, it was not surprising that the DE values followed a similar pattern.
It has been generally reported that protease supplementation can improve protein digestion and bird performance (Cowieson and Roos, 2016; Cowieson et al., 2019; Walk et al., 2019), and is particularly beneficial when applied in the proper context, such as in low protein diets with inadequate AA concentrations. In this context, protease may be applied to reduce maintenance energy costs (i.e. pancreatic and biliary secretions). Moreover, it may be possible to use protease to combat excess lipid accumulation associated with low protein diets. Plavink and Hurwitz (1990) showed that broilers and turkey poults, subjected to low sodium or low protein diets with feed restriction, recovered either body weight or feed conversion over time. This compensatory recovery was accompanied by a lower amount of abdominal fat pad. This illustrates the point that manipulation of the concentration or type of key nutrients, such as protein, can lead to complex changes in body tissue accretion, such as adipocyte development, which can have implications on growth rate and carcass characteristics.

The findings from the current study demonstrated that protease supplementation may be applied to improve net energy in broiler diets by altering maintenance energy requirements. However, additional research evaluating this and the mechanisms by which this occurs is warranted.

\section{Conflict of interest}

The authors declare no conflict of interest.

\section{References}

Almirall, M. and Esteve-Garcia, E., 1994. Rate of passage of barley diets with chromium oxide: influence of age and poultry strain and effect of $\beta$-glucanase supplementation. Poultry Science 73: 1433-1440.

Annison, E. and White, R., 1961. Glucose utilisation in sheep. Biochemical Journal 80: 162-169.

AOAC, 2005. Official methods of analysis. $18^{\text {th }}$ edition. Horwitz, W. and Latimer, G.W. (eds.). Association of Official Agricultural Chemists International, Gaithersburg, MD, USA.

Barzegar, S., Wu, S.B., Choct M. and Swick, R.A., 2020. Factors affecting energy metabolism and evaluating net energy of poultry feed. Poultry Science 99(1): 487-498.

Brouwer, E., 1965. Report of sub-committee on constants and factors. In: Blaxter, K.L. (ed.) Energy metabolism. EAAP Publication. No. 11. Academic Press, London, UK, pp. 441-443.

Cowieson, A.J. and Roos, F.F., 2014. Bioefficacy of a mono-component protease in the diets of pigs and poultry: a meta-analysis of effect on ileal amino acid digestibility. Journal of Applied Animal Nutrition 2: 13-21.

Cowieson, A.J. and Roos, F.F., 2016. Toward optimal value creation through the application of exogenous mono-component protease in the diets of non-ruminants. Animal Feed Science and Technology 221(B): 331-340. 
Cowieson, A.J., Toghyani, M., Kheravii, S.K., Wu, S.B., Romero, L.F. and Choct, M., 2019. A mono-component microbial protease improves performance, net energy, and digestibility of amino acids and starch, and upregulates jejunal expression of genes responsible for peptide transport in broilers fed corn/wheat-based diets supplemented with xylanase and phytase. Poultry Science 98(3): 1321-1332.

Emmans, G.C., 1994. Effective energy: a concept of energy utilisation applied across species. British Journal of Nutrition 71(6): 801-821.

Kleyn, R. and Chrystal, P., 2020. Broiler nutrition: masterclass. Context Publications, Packington, UK, pp. 231-251.

Kluth, H. and Rodehutscord, M. 2009. Effect of inclusion of cellulose in the diet on the inevitable endogenous amino acid losses in the ileum of broiler chicken. Poultry Science 88: 1199-1205.

Labussière, E., Van Milgen, J., De Lange, C.F. and Noblet, J., 2011. Maintenance energy requirements of growing pigs and calves are influenced by feeding level. The Journal of Nutrition 141: 1855-1861.

Lazaro, R., Garcia, M., Medel, P. and Mateos, G.G., 2003. Influence of enzymes on performance and digestive parameters of broilers fed rye-based diets. Poultry Science 82: 132-140.

Lemme, A., Hiller, P., Klahsen, M., Taube, V., Stegemann, J. and Sirmon, I., 2019. Reduction of dietary protein in broiler diets not only reduces $\mathrm{n}$-emmissions but is also accompanied by several further benefits. Journal of Applied Poultry Research 28: 867-880. https://doi.org/10.3382/japr/pfz045

Liu, S., Selle, P., Court, S. and Cowieson, A., 2013. Protease supplementation of sorghum-based broiler diets enhances amino acid digestibility coefficients in four small intestinal sites and accelerates their rates of digestion. Animal Feed Science and Technology 183: 175-183.

Liu, W., Lin, C.H., Wu, Z.K., Liu, G.H., Yan, H.J., Yang, H.M. and Cai, H.Y., 2017. Estimation of the net energy requirement for maintenance in broilers. Asian-Australasian Journal of Animal Sciences 30: 849-856.

Lopez, G. and Leeson, S., 2008. Review: energy partitioning in broiler chickens. Canadian Journal of Animal Science 88: 205-212.

Mahagna, M., Nir, I., Larbier, M. and Nitsan, Z., 1995. Effect of age and exogenous amylase and protease on development of the digestive tract, pancreatic enzyme activities and digestibility of nutrients in young meat-type chickens. Reproduction Nutrition Development 35: 201-212.
National Health and Medical Research Council, 2013. Australian code of practice for the care and use of animals for scientific purposes. $8^{\text {th }}$ edition. Australian Government Public Service. Available at: https://www.nhmrc.gov.au/about-us/publications/australian-codecare-and-use-animals-scientific-purposes\#block-views-block-fileattachments-content-block-1.

Noblet, J., Dubois, S., Lasnier, J., Warpechowski, M., Dimon, P., Carré, B., Van Milgen, J. and Labussière, E., 2015. Fasting heat production and metabolic BW in group-housed broilers. Animal 9: 1138-1144.

Noblet, J., Fortune, H., Shi, X.S. and Dubois, S., 1994. Prediction of net energy value of feeds for growing pigs. Journal of Animal Science 72: 344-354. https://doi.org/10.2527/1994.722344x

Plavnik, I. and Hurwitz, S., 1990. Performance of broiler chickens and turkey poults subjected to feed restriction or to feeding of low-protein or low-sodium diets at an early age. Poultry Science 69(6): 945-952.

Riesenfeld, G., Sklan, D., Bar, A., Eisner, U. and Hurwitz, S., 1980. Glucose absorption and starch digestion in the intestine of the chicken. Journal of Nutrition 110: 117-121.

Ross, 2014. Ross 308 broiler: nutrition specifications (all plant-protein based feeds). Aviagen. Available at: http://garantitavukculuk.com/ doc/Ross_nutrition_spec.pdf.

SAS Institute, 2015. SAS 9.4 user's guide - statistics. SAS Institute Inc., Cary, NC, USA.

Short, F.J., Gorton, P., Wiseman, J. and Boorman, K.N., 1996. Determination of titanium dioxide added as an inert marker in chicken digestibility studies. Animal Feed Science Technology 59: 215-221.

Vieira, S.L. and Lima, I.L., 2005. Live performance, water intake and excreta characteristics of broilers fed all vegetable diets based on corn and soybean meal. International Journal of Poultry Science 4(6): $365-368$

Walk, C.L., Juntunen, K., Paloheimo, M. and Ledoux, D.R., 2019. Evaluation of novel protease enzymes on growth performance and nutrient digestibility of poultry: enzyme dose response. Poultry Science 98(11): 5525-5532.

Wu, S.-B., Swick, R.A., Noblet, J., Rodgers, N., Cadogan, D. and Choct, M., 2019. Net energy prediction and energy efficiency of feed for broiler chickens. Poultry Science 98: 1222-1234. 
